10. Hartmann, E., Baekeland, F., Zwilling, G., and Hoy, P.: Sleep need: how much sleep and what kind? Amer. J. Psychiat., 127: 1001 (1971).

11. Hawkins, D. R. and Mendels, J.: Sleep disturbance in depressive syndromes. Amer. J. Psychiat., 123: 682 (1966).

12. Kupfer, D. J.: REM latency: a psychobiologic marker for primary depressive diseases. Biol. Psychiat., II: 159 (1976).

13. Orr, C. W., Vogel, G. W., Stahl, M. L., Griffiths, W. J., and Seely, J. R.: Sleep patterns in growth hormone deficient children and age-matched controls: developmental considerations. Neuroendocrinology, 24: 347 (1977).

14. Patton, R. G. and Gardner, I. L.: Influence of family environment on growth: the syndrome of "maternal deprivation." Pediatrics, 30: 957 (1962).

15. Powell, G. F., Brasel, J. A., and Blizzard, R. M.: Emotional deprivation and growth retardation simulating idiopathic hypopituitarism. I. Clinical evaluation of the syndrome. N. Engl. J. Med., 276: 1271 (1967).

16. Powell, G. F., Brasel, J. A., Raiti, S., and Blizzard, R. M.: Emotional deprivation and growth retardation simulating idiopathic hipopituitarism. II. Endocrinologic evaluation of the syndrome. New Engl. J. Med., 276: 1279 (1967).

17. Powell, G. F., Hopwood, N. J., and Barratt, E. S.: Growth hormone studies before and during catch up growth in a child with emotional deprivation and short stature. J. Clin. Endocrin., 37: 674-679 (1973).

18. Rechtschaffen, A. and Kales, A. Ed.: A manual of standardized terminology, techniques and scoring systems for sleep stages of human subjects. Washington, D.C.: Public Health Service, U.S. Government Printing Office (1968).

19. Sassin, J. F., Parker, D. C., Mace, J. W., Gotlin, R. W., Johnson, L. C., and Rossman, L. G.: Human growth hormone release: relation to slow-wave sleep

Copyright $(1) 1982$ International Pediatric Research Foundation, Inc.

$0031-3998 / 82 / 1604-0299 \$ 2.00 / 0$ and sleep-waking cycles. Science, 165: 513 (1969).

20. Schimpff, R. M., Donnadieu, M., and Combourieu, M.: Dosage radioimmunologique de l'hormone de croissance humaine plasmatique. Path. Biol., 18: 241 (1970).

21. Silver, H. K. and Finkelstein, M.: Deprivation dwarfism. J. Pediatr., 70: 317 (1967).

22. Takahashi, Y., Kipnis, D. M., and Daughaday, W. H.: Growth hormone secretion during sleep. J. Clin. Invest., 47: 2079 (1968).

23. Underwood, L. E., Azumi, K., Voina, S., and Van Wyk, J. J.: Growth hormone levels during sleep in normal and growth hormone deficient children. Pediatrics, 48 : 946 (1971).

24. Webb, W. B. and Agnew, H. W.: Effects of a restricted regime. Science, 150: 1745 (1965)

25. Weitzman, E. D., Kripke, D. F., Goldmacher, D., McGregor, P., and Nogueire, C.: Acute reversal of the sleepwake cycle in man. Arch. Neurol., 22: 483 (1970).

26. Wolff, G. and Money, J.: Relationship between sleep and growth in patients with reversible somatotropin deficiency (psychosocial dwarfism). Psychol. Med., 3: 18 (1973).

27. The authors thank David Roulack and Susan Orsoni for their help with the English version of this manuscript.

28. Requests for reprints should be addressed to: Mrs. O. Benoit, Laboratoire de Physiologie, 91, Boulevard. de l'Hôpital, F-75634 Paris Cedex 13, France.

29. Received for publication March 11, 1981.

30. Accepted for publication August, 198I.

\title{
SYMPOSIUM ON THE PREVENTION OF CORONARY HEART DISEASE
}

This program is intended for practicing physicians, nurses, physician's assistants, medical students and epidemiologists who are interested in the principles and practice of preventive cardiology.

Dates: $\quad$ May 17 and 18, 1982

Where: University of Iowa Memorial Union

Iowa City, Iowa

Sponsored by: University of Iowa College of Medicine

Preventive Cardiology Academic Award of the National Heart, Lung \& Blood Institute

American Heart Association, Iowa Affiliate

Merck, Sharp and Dome, Educational Grant

Guest Faculty:

Lewis Kuller, M.D.

Donald Riopel, M.D.

William McFate Smith, M.D,

Paul Thompson, M.D.

H. A. Tyroler, M.D.
University of Iowa Faculty:

Arthur Canter, Ph.D.

E. Peter Isacson, M.D.

Ronald M. Lauer, M.D.

James L. Massey, M.A.

Robert E. Rakel, M.D.

Richard M. Schieken, M.D.

Robert B. Wallace, M.D.

Printed in U.S.A.

Course Director:
Credit:

Further information: Ms. Diane Case, Research Assistant, Office of Consultation and Research in Medical Education, W103 CH, University of Iowa, Iowa City, IA 52242 